Research Article

\title{
Identification of thalassemia carrier in anemic pregnant women at Puskesmas Kertapati Palembang: comparison of five erythrocyte indices
}

\author{
Mitayani Purwoko ${ }^{1,2^{*}}$, Eriko Erenkwot ${ }^{3}$ \\ 1) Staff of Departement of Medical Biology, Faculty of Medicine, Universitas Muhammadiyah Palembang \\ 2) Student of Doctoral Program of Medicine, Faculty of Medicine, Sebelas Maret University, Surakarta \\ 3) Student of Medical Professional Study Program, Faculty of Medicine, Universitas Muhammadiyah Palembang
}

A R T I C L E I N F O

\begin{tabular}{ll}
\hline Submitted & : March 2020 \\
Accepted & : August 2020 \\
Published & : January 2021 \\
\hline
\end{tabular}

\section{Keywords:}

anemia, Thalassemia, pregnant woman, erythrocyte index

\section{*Correspondence:}

mitayani.dr@gmail.com

\section{ABSTRACT}

Anemia is a condition that is almost always found in pregnancy. Although a program of Fe tablets has been introduced during pregnancy, the prevalence of anemia during pregnancy is still high. This situation may be caused by another risk factor of anemia, such as Thalassemia. This study was aimed to investigate the presence of carrier Thalassemia in pregnant women at the Puskesmas Kertapati, Palembang, South Sumatera, using erythrocyte indices. This is a cross-sectional study with a sample size of 68 subjects, taken by purposive sampling technique. The hemoglobin level of all subjects was measured by Easy touch GCHb and confirmed by Sysmex K21. Differences in hemoglobin between Easy Touch GCHb and Sysmex K21 were analyzed by impaired t-test used SPSS program. Other data were analyzed using descriptive statistics. The mean hemoglobin levels in subjects were $10.7 \mathrm{~g} / \mathrm{dl}$. There were 68 subjects have anemia according to Easy Touch $\mathrm{GCHb}$, but only 30 subjects confirmed positive anemia by Sysmex KX 21. The T-test result gave a p-value $<0.05$ that is considered there was a statistically significant difference between Easy Touch GCHb and Sysmex KX 21 results $(p=0.001)$. Calculations using the England-Fraser index, Mentzer, Sirdah, and Srivastava indicate that none of the research subjects had thalassemia carrier status. 


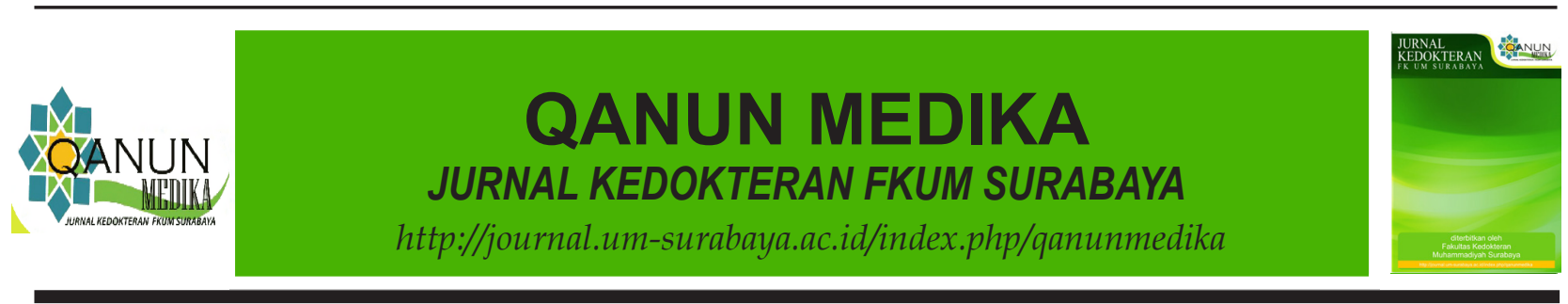

\section{INTRODUCTION}

Anemia is a circumstance that is almost always found in pregnancy. It is estimated that the prevalence reaches $18 \%$ in developed countries and $35-75 \%$ in developing countries in 2017 (Öztürk et al., 2017). In Indonesia, the proportion of Thalassemia carriers among blood donors in Banyumas was 8.74\% (Hapsari and Rujito, 2015). Anemia in pregnancy is a physiological condition due to an increase in maternal blood volume. This condition is called hemodilution. If left unhindered, anemia in pregnancy is associated with increased morbidity and mortality for both mother and baby (Stephen et al., 2018).

The most common cause of anemia in pregnancy is iron deficiency anemia (IDA) because there is an increasing need for iron throughout pregnancy (Alene and Dohe, 2014). Until this research report was made, there was no global data on the prevalence of anemia in pregnancy, but several reports showed a prevalence of $18-46.2 \%$ (Suega et al., 2002; Sukrat et al., 2010; Suryanarayana et al., 2017; Srour et al., 2018; Stephen et al., 2018). There are no national data in Indonesia about the prevalence of this disease. Several studies conducted in various regions in Indonesia in the last five years showed a prevalence between 26.7-42.6\% (Astriana, 2017; Astuti and Kulsum, 2018).

The high prevalence rate of anemia in pregnancy raises a question because the Ministry ofHealth of the Republic of Indonesia has established a program of giving Fe tablets to all pregnant women who come to health facilities during antenatal care. Therefore, other causes of anemia in pregnancy need to be considered, such as infection, nutritional deficiencies other than iron, and Thalassemia.

Thalassemia is a genetic disorder characterized by abnormalities in erythrocytes, precisely in the globin chains' arrangement. The disorder causes the erythrocytes to undergo lysis, resulting in anemia (Viprakasit and Ekwattanakit, 2018). This disease is inherited from carrier parents to their children through the autosomal recessive pathway (Angastiniotis and Lobitz, 2019). Thus, the diagnosis of carrier Thalassemia is important to prevent the inheritance of the children. However, the definitive diagnosis of Thalassemia or the carrier requires enormous costs, so various calculations are used, which will increase the sensitivity and specificity of one another when used together. Some calculations that can be used to establish a carrier diagnosis of Thalassemia are England-Fraser index (MCVRBC-5xHb-3.4), Mentzer index (MCV/RBC), Sirachainan index (1.5xHb-0.05MCV), Sirdah index (MCV-RBC-3xHb), and Srivastava index $(\mathrm{MCV} / \mathrm{RBC})$. This study was aimed to investigate the incidence of carrier Thalassemia in pregnant women at Puskesmas Kertapati, Palembang, South Sumatera, Indonesia, using erythrocyte indices. Erythrocyte indices are used to differentiate iron deficiency anemia or thalassemia carrier which causes anemia in a person.

\section{METHODS}

This study was a cross-sectional study. The sample size of 68 subjects was acquired by purposive sampling. Inclusion criteria for this study were pregnant women with anemia and pregnant women undertaking antenatal care and consumed $\mathrm{Fe}$ tablets routinely at Puskesmas Kertapati, Palembang, South Sumatera during October-December 2019. This study's exclusion criteria were pregnant women who were experiencing bleeding in the digestive tract, urinary tract, or respiratory tract.

Determination of anemia status $(\mathrm{Hb} \leq 11 \mathrm{~g} /$ dL) was done in two ways. Step one, the hemoglobin $(\mathrm{Hb})$ level of pregnant women, was examined using the Easy Touch GCHb (Bioptik Technology Inc., Taiwan) at Puskesmas 
Kertapati. Easy Touch is an automated blood analyzer that gives a quick result, and at a relatively low price, this tool is very widely used in first-level health facilities. In step two, the $\mathrm{Hb}$ level, red blood cells (RBC), and Mean Corpuscular Volume (MCV) of pregnant women who had anemia, according to Easy Touch GCHb, were examined using Sysmex KX 21 (Sysmex Corporation, Japan) at Palembang Health Laboratory Center. Sysmex KX 21 is an automated hematology analyzer, a standard diagnostic tool for hematology analysis. The erythrocyte index used was limited to 5 indices calculated using the $\mathrm{Hb}, \mathrm{MCV}$, and RBC values. The Ethical Committee of Faculty of Medicine Universitas Muhammadiyah Palembang approved this study with certificate No. 51/EC/ KBHKI/FK-UMP/XI/2019.
All statistical data were analyzed by the SPSS program. Unpaired t-test was applied with $\alpha$ value $95 \%$ so $p$-value less than 0.05 considered as statistically significant. The mean value of $\mathrm{Hb}$ level, $\mathrm{RBC}, \mathrm{MCV}$, and anemia distribution based on pregnancy was analyzed using descriptive statistic analysis.

\section{RESULTS}

The results of $\mathrm{Hb}$ measurement using Easy Touch $\mathrm{GCHb}$ showed that the mean $\mathrm{Hb}$ of this study was $9.37 \mathrm{~g} / \mathrm{dL}$, and the majority had mild anemia (82.4\%). The $\mathrm{Hb}$ measurement results using Sysmex KX 21 showed that the mean $\mathrm{Hb}$ of this study was $10.79 \mathrm{gr} / \mathrm{dL}$. The t-test result showed a $p$-value $<0.05$, so there was a significant difference between Easy Touch GCHb and Sysmex KX 21. This result is summarized in table 1 .

Table 1. Mean of Hemoglobin using two measurements ( $\mathrm{n}=68$ subjects)

\begin{tabular}{lccc}
\hline & Easy Touch & Sysmex & p-value \\
\hline Mean $\mathrm{Hb}$ in g/dL (SD) & $9.37(1.23)$ & $10.79(1.66)$ & 0.001 \\
Mean MCV & - & 95.16 & - \\
Mean RBC & - & 3.64 & - \\
\hline
\end{tabular}

The results of $\mathrm{Hb}$ measurement using Easy Touch $\mathrm{GCHb}$ showed in Table 2 that the majority of respondents who had anemia were in trimester III (25 peoples or $36.76 \%$ ), while according to the results of the Sysmex, the majority were in trimester II (18 peoples or $26.47 \%$ ).

Table 2. Distribution of anemia based on pregnancy trimester ( $\mathrm{n}=68$ subjects)

\begin{tabular}{ccc}
\hline Trimester & Easy Touch & Sysmex K21 \\
\hline I & $23(33.8 \%)$ & $11(16.2 \%)$ \\
II & $20(29.4 \%)$ & $18(26.5 \%)$ \\
III & $25(36.8 \%)$ & $9(13.2 \%)$ \\
\hline
\end{tabular}




\section{QANUN MEDIKA Vol 5 No 1 JANUARY 2021}

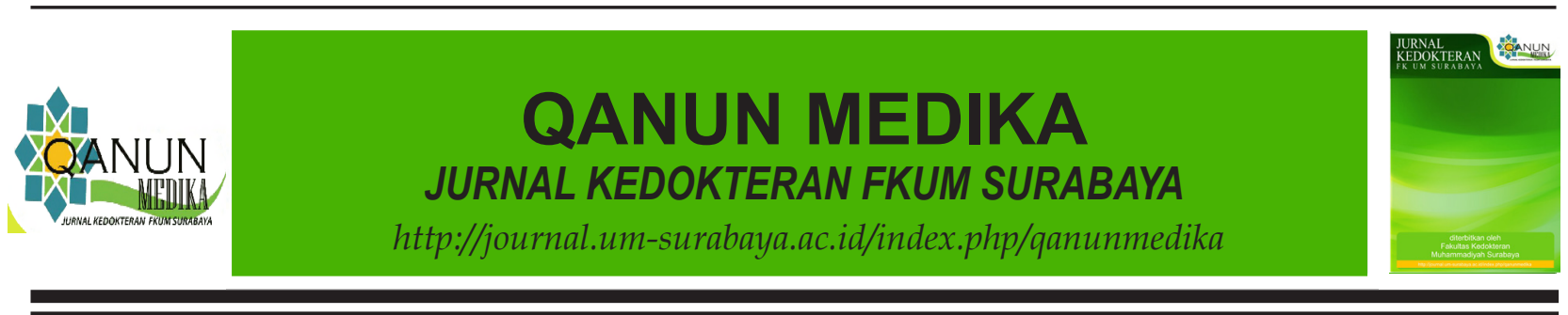

Table 3. Erythrocyte indices result ( $\mathrm{n}=68$ subjects)

\begin{tabular}{|c|c|c|c|}
\hline Index & Cut-off point & $\begin{array}{c}\text { Iron Deficiency } \\
\text { Anemia }\end{array}$ & $\begin{array}{c}\text { Thalassemia } \\
\text { carrier }\end{array}$ \\
\hline $\begin{array}{l}\text { England-Fraser } \\
\text { (MCV-RBC-5xHb-3.4) }\end{array}$ & $\begin{array}{c}\mathrm{TC}<0 \\
\mathrm{IDA}>0\end{array}$ & $68(100.0 \%)$ & $0(0.0 \%)$ \\
\hline Mentzer (MCV/RBC) & $\begin{array}{c}\mathrm{TC}<13 \\
\mathrm{IDA} \geq 13\end{array}$ & $68(100.0 \%)$ & $0(0.0 \%)$ \\
\hline Sirdah (MCV-RBC-3xHb) & $\begin{array}{c}\mathrm{TC}<27 \\
\mathrm{IDA} \geq 27\end{array}$ & $68(100.0 \%)$ & $0(0.0 \%)$ \\
\hline Srivastava (MCV/RBC) & $\begin{array}{c}\mathrm{TC}<3.8 \\
\mathrm{IDA} \geq 3.8\end{array}$ & $68(100.0 \%)$ & $0(0.0 \%)$ \\
\hline Sirachainan (1.5xHb-0.05MCV) & $\begin{array}{c}\mathrm{TC}<14 \\
\mathrm{IDA} \geq 14\end{array}$ & $58(85.3 \%)$ & $10(14.7 \%)$ \\
\hline
\end{tabular}

\section{DISCUSSION}

The mean hemoglobin levels in subjects were $10.7 \mathrm{~g} / \mathrm{dl}$. This value was similar to the mean hemoglobin levels of Cameroon pregnant women but lower than pregnant women in Northwest Morocco who have a mean hemoglobin level of $11.80 \mathrm{~g} / \mathrm{dl}$ (Kimbi et al., 2017; Bakrim et al., 2018). Hemoglobin in pregnancy will decline during the first trimester and going further until the second trimester. Nevertheless, during the third trimester, the hemoglobin will rise (Li et al., 2017). This study found the result was similar to that theory because the lowest number of anemic pregnant women was in the trimester 3 group $(13.2 \%)$, and the most significant number was in the trimester 2 group (26.5\%). Anemia in pregnancy is considered as one of the major risk factors for contributing $20-40 \%$ of maternal deaths directly or indirectly through cardiac failure, preeclampsia, antepartum hemorrhage, postpartum hemorrhage, and puerperal sepsis. It is also responsible for low birth weight, which in turn might contribute to an increased percentage of infant mortality (Prakash and Yadav, 2015).

This study used two hemoglobin measurements to determine anemia status in research subjects, the Easy Touch GCHb and the Sysmex KX
21. This study indicated that 30 subjects did not have anemia according to the Sysmex KX 21 but classified as anemia according to the Easy Touch GCHb. Statistical analysis showed a statistically significant difference in mean $\mathrm{Hb}$ between these two instruments ( $p=0.001)$. Easy Touch GCHb measures the hemoglobin level from capillary blood, while Sysmex KX 21 measures hemoglobin level from venous blood. This occurs because a drop of capillary blood reflects the capillaries, arterioles, and venules, while venous blood reflects blood vessels, hearts, and arteries. Examination using Sysmex, which has the way flow cytometry, certainly has the advantage of getting a high accuracy hemoglobin value. While the examination of hemoglobin using Easy Touch GCHb works by measuring two wavelengths, namely 565 and 880 nm (Patel et al., 2013).

This study also showed that the majority of pregnant women with anemia were in the third trimester (36.76\%) according to Easy Touch GCHb, but according to Sysmex KX 21 measurement, the majority of pregnant women with anemia were in the second trimester $(26.47 \%)$. These results are generally the same as various existing theories, namely anemia in pregnancy generally occurs in trimesters II and III. This is due at that time because of an increase in maternal blood plasma volume up 
to $50 \%$, resulting in hemodilution. Besides, iron demand also increases because the need for fetal erythrocyte production will increase rapidly in the second trimester. Without adequate iron intake, iron needs will be difficult to fulfill, thus disrupting erythrocytes production (Shagana et al., 2018). However, anemia can occur every trimester in pregnancy (Paendong, Suparman, and Tendean, 2016; Amini, Pamungkas, and Harahap, 2018).

Calculations using the England-Fraser index, Mentzer, Sirdah, and Srivastava indicate that none of the research subjects had thalassemia carrier status. Meanwhile, calculation using the Sirachainan index indicated that there were 10 Thalassemia carriers (14.7\%). The Mentzer index has a sensitivity of $89.01 \%$ and a specificity of $78.65 \%$, ranked $3^{\text {rd }}$ in terms of the accuracy of the 28 indexes used in his study. The Sirdah index has a sensitivity of $80.26 \%$ and a specificity of $88.65 \%$, ranked $5^{\text {th }}$. The Srivastava index has a sensitivity of $74.86 \%$ and specificity of $80.81 \%$, ranked $16^{\text {th }}$. The England-Fraser index has a sensitivity of $62.94 \%$ and specificity of $85.41 \%$, ranked $19^{\text {th }}$. And, the Sirachainan had a sensitivity of $35.94 \%$ and specificity of $74.86 \%$, ranked $25^{\text {th }}$. Sirachainan index has the lowest sensitivity among five erythrocyte indices (Jahangiri, Rahim and Malehi, 2019). Low sensitivity means that the index is not capable enough to classify pregnant women as a Thalassemia carrier (Parikh et al., 2008).

Thalassemia is a genetic disease with anemia as the dominant clinical manifestation. An autosomal recessive pattern inherits this disease. The autosomal recessive disease will need two alleles to manifest. People with one allele of mutation for Thalassemia will not manifest the symptoms. This people are called carriers. Both Thalassemia type, alpha and beta, have the carrier. This study did not go through a standard diagnostic tool, which is Hemoglobin electrophoresis, because the screening test found no one as a Thalassemia carrier. Suppose there is a subject with a positive result for thalassemia carrier in this study. In that case, the subject's blood will be sent to the laboratory for hemoglobin electrophoresis examination and determined what type of Thalassemia do the carriers have.

Based on the accuracy of the five indices used in this study, the Sirachainan index has the weakest accuracy. The sensitivity value is $<50 \%$, which means that the Sirachainan index is not suitable for screening a Thalassemia carrier. Thus, the difference in results on calculations using the Sirachainan index can be ignored because other indices' sensitivity was more than $50 \%$.

\section{CONCLUSION}

There was no Thalassemia carrier in anemic pregnant women at Puskesmas Kertapati, Palembang, South Sumatera based on EnglandFraser index, Mentzer index, Sirdah, and Srivastava index.

\section{ACKNOWLEDGEMENT}

The staff of Puskesmas Kertapati Palembang, South Sumatera, for the permission and helping hand throughout the data collection. The staff of Balai Besar Laboratorium Kesehatan Palembang, South Sumatera, for the service of blood examination.

\section{REFERENCES}

Alene, K.A. and Dohe,A.M.(2014) 'Prevalence of Anemia and Associated Factors among Pregnant Women in an Urban Area of Eastern Ethiopia', Anemia, 561567, pp. 1-7. Available at: https://www.hindawi. com/journals/anemia/2014/561567/.

Amini, A., Pamungkas, C. E. and Harahap, A. P. (2018) 'Umur ibu dan paritas sebagai faktor risiko yang mempengaruhi kejadian anemia pada ibu hamil di 


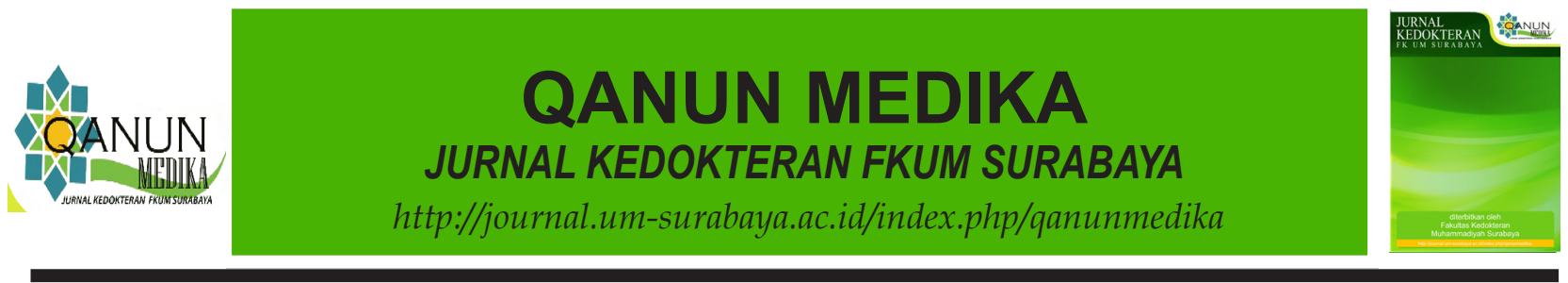

wilayah kerja puskesmas ampenan', Midwifery Journal, 3(2), pp. 108-113. Available at: http://journal.ummat.ac.id/ index.php/MJ/article/view/506/pdf.

Angastiniotis, M. and Lobitz, S. (2019) 'Thalassemias : An Overview', International Journal of Neonatal Screening, 5(16), pp. 1-11. doi: 10.3390/ ijns5010016.

Astriana, W. (2017) 'Kejadian Anemia pada Ibu Hamil Ditinjau dari Paritas dan Usia', Aisyah: Jurnal Ilmu Kesehaan, 2(2), pp. 123-130. Available at: https:// aisyah.journalpress.id/index.php/jika/ article/view/WA.

Astuti, D. and Kulsum, U. (2018) 'Pola makan dan umur kehamilan trimester iii dengan anemia pada ibu hamil', Indonesia Jurnal Kebidanan, 2(1), pp. 24-30. Available at: https://ejr.stikesmuhkudus. ac.id/index.php/ijb/article/view/448.

Bakrim, S. et al. (2018) 'Hematological parameters of the blood count in a healthy population of pregnant women in the Northwest of Morocco (TetouanM' diq -Fnideq provinces)', Pan African Medical Journal, 29(205). doi: 10.11604/ pamj.2018.29.205.13043.

Hapsari, A. T. and Rujito, L. (2015) 'Uji Diagnostik Indeks Darah dan Identifikasi Molekuler Karier Talasemia $\beta$ pada Pendonor Darah di Banyumas Blood Donor Subjects in Banyumas', Jurnal Kedokteran Brawijaya, 28(3), pp. 233237. Available at: https://jkb.ub.ac.id/ index.php/jkb/article/view/595.

Jahangiri, M., Rahim, F. and Malehi, A. S. (2019) 'Diagnostic performance of hematological discrimination indices to discriminate between $\beta$ eta thalassemia trait and iron deficiency anemia and using cluster analysis : Introducing two new indices tested in Iranian population', Scientific Reports. Springer US, 9(18610). doi: 10.1038/s41598-019-54575-3.

Kimbi, J. K. A. et al. (2017) 'Profile of red blood cell morphologies and causes of anaemia among pregnant women at first clinic visit in the mount Cameroon area : a prospective cross sectional study', $B M C$ Research Notes. BioMed Central, 10(645), pp. 1-7. doi: 10.1186/s13104-017-2961-6.

Li, A. et al. (2017) 'Establishment of reference intervals for complete blood count parameters during normal pregnancy in Beijing', J Clin Lab Anal, 31(e22150), pp. 1-7. doi: 10.1002/jcla.22150.

Öztürk, M. et al. (2017) 'Anemia prevalence at the time of pregnancy detection', Turk J Obstet Gynecol, 14, pp. 176-180. doi: 10.4274/tjod.06337.

Paendong, F. T., Suparman, E. and Tendean, H. M. M. (2016) 'Profil zat besi ( Fe ) pada ibu hamil dengan anemia di Puskesmas Bahu Manado', Jurnal e-Clinic, 4(1), pp. 369-374. Available at: https://ejournal. unsrat.ac.id/index.php/eclinic/article/ view/10985.

Parikh, R. et al. (2008) 'Understanding and using sensitivity, specificity and predictive values', Indian Journal of Ophthalmology, 56(1), pp. 45-50. Available at: http:// www.ijo.in/downloadpdf.asp?issn $=0301$ 4738; year $=2008$; volume $=56$; issue $=1$; spa ge $=45$; epage $=50$; aulast $=$ Parikh;type $=2$.

Patel, A. J. et al. (2013) 'Capillary versus Venous Hemoglobin Determination in the Assessment of Healthy Blood Donors', Vox Sang, 104(4), pp. 317-323. doi: 10.1111/vox.12006.Capillary.

Prakash, S. and Yadav, K. (2015) 'Maternal Anemia in Pregnancy: An Overview', International Journal of Pharmacy \& Pharmaceutical Research, 4(3), 
pp. 164-179. Available at: http:// ijppr.humanjournals.com/wp-content/ uploads/2015/11/14. Satyam-PrakashKhushbu-Yadav.pdf.

Shagana, J. et al. (2018) 'Physiological changes in pregnancy', Drug Invention Today, 10(8), pp. 1594-1597. Available at: http://jprsolutions.info/article_detail. php?article_id=2438.

Srour, M. A. et al. (2018) 'Prevalence of Anemia and Iron Deficiency among Palestinian Pregnant Women and Its Association with Pregnancy Outcome', Anemia. Hindawi, 2018(9135625). doi: $10.1155 / 2018 / 9135625$.

Stephen, G. et al. (2018) 'Anaemia in Pregnancy : Prevalence, Risk Factors , and Adverse Perinatal Outcomes in Northern Tanzania', anemia, 2018(1846280). Available at: https://www.hindawi.com/ journals/anemia/2018/1846280/.

Suega, K. et al. (2002) 'Iron-deficiency anemia in pregnant women in Bali, Indonesia : a profile of risk factors and', the southeast asian journal of tropical medicine and public health, 33(3), pp. 604-607. Available at: https://www.tm.mahidol. ac.th/seameo/2002_33_3/25-2821.pdf.

Sukrat, B. et al. (2010) 'The Prevalence of Iron Deficiency Anemia in Pregnant Women in Nakhonsawan, Thailand', J Med Assoc Thai, 93(7), pp. 765-770. Available at: http://www.jmatonline.com/index.php/ jmat/article/view/282\#.

Suryanarayana, R. et al. (2017) 'Prospective study on prevalence of anemia of pregnant women and its outcome: A community based study', Journal of Family Medicine and Primary Care, 6, pp. 739-743. doi: 10.4103/jfmpc.jfmpc.

Viprakasit, V. and Ekwattanakit, S. (2018) 'Clinical Classification, $\mathrm{S}$ cree ning an d D i ag n o si s f or Tha las s emi a', Hematology/Oncology Clinics of North America. Elsevier Inc, 32(2), pp. 193211. doi: 10.1016/j.hoc.2017.11.006. 